Conceptualization of the existential-system model of reorganization of the "worldview" of the personality: the introduction of ontological dominants

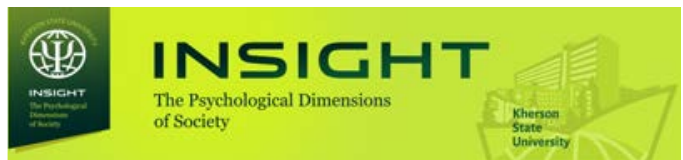

DOI: $10.32999 / 2663-970 X / 2020-3-1$

Link article (Style APA): Kalishchuk, S. M. (2020). Conceptualization of the existential-system model of reorganization of the "worldview" of the personality: the introduction of ontological dominants. Insight: the psychological dimensions of society, 3, 11-27. DOI: 10.32999/2663-970X/2020-3-1

Link article (Style DSTU 8302: 2015): Kalishchuk, S. M. Conceptualization of the existential-system model of reorganization of the "worldview" of the personality: the introduction of ontological dominants. Insight: the psychological dimensions of society, 2020, 3, 11-27. DOI: 10.32999/2663-970X/2020-3-1

UDC 159.9.015

\title{
Conceptualization of the existential-system model of reorganization of the "worldview" of the personality: the introduction of ontological dominants
}

\section{Концептуалізація екзистенціально-системної моделі реорганізації “картини світу” особистості: введення онтологічних домінант}

\author{
Received: March 30, 2020 Accepted: May 22, 2020
}

Kalishchuk Svitlana Mykolaivna

PhD in Psychology,

Assistant Professor,

Doctoral Student of Psychology of Personality and Social Practices Department of Institute of Human Sciences of Borys

Grinchenko Kyiv, Ukraine

Klana_@ukr.net, ORCID 0000-0002-1749-7856

\section{Abstract}

Purpose. The article highlights the successive steps of conceptualization of trans-theoretical existential-system approach to the reorganization of the semantic architectonics of personality consciousness. Methods. Spectral, structural and semiotic approaches provided a comprehensive methodological analysis of the procedural action of the existential-system concept. Results. An ontological field of the semantic model of the world of personality has been constructed. Five projections of the study of the personality have been revealed. The key concepts of theoretical design of the concept have been defined: "world", "consciousness", "worldview", "meaning", "system", "semantic architectonics of consciousness", "representations-experiences-thoughts", "reorganization", "self-attribution". They describe the inner space of the psychological system

\author{
Каліщук Світлана Миколаївна \\ кандидат психологічних наук, \\ доцент, докторант кафедри психології \\ особистості та соціальних практик \\ Інституту людини, Київський \\ університету імені Бориса Грінченка, \\ Україна \\ Klana_@ukr.net, \\ ORCID 0000-0002-1749-7856
}

\section{Анотація}

Мета.У статті висвітлено послідовні кроки концептуалізації транстеоретичного екзистенціально-системного підходу до реорганізації смислової архітектоніки свідомості особистості. Методи. Спектральний, структурний та семіотичний підходи забезпечили комплексний методологічний аналіз процесуальної дії екзистенціально-системного концепту. Результати. Побудовано онтологічне поле смислової моделі світу особистості. Розкрито п'ять проекцій дослідження екзистенціальної дійсності людини. Визначено ключові поняття теоретичного оформлення концепту: “світ", “свідомість”, “картина світу”, “смисл”, “система”, “смислова архітектоніка свідомості”, “уявлення-переживання-думки”, “реорганізація”, “самовіднесення", що описують внутрішній простір психологічного ладу екзистенціально-системного 
of the existential-system concept, which is operated by a psychologist-specialist. A visual model of the theoretical construct of the existential-system approach has been constructed. It reflects the client's representations. A meaningful scheme of interrelationships and interactions of ontological representations of eight perspectives of "correlation with the world" as an action of finding meaning has been offered. Diagnostic approaches' complementarity has been substantiated. The connection scheme of elements of diagnostic-correctional approaches of existential-system concept of reorganization of the individual "worldview" has been offered: existential, system modeling and psychodrama, projective, psychosemantic, body-dynamic and transpersonal. The technical methods that objectively outline the methodological potential of the existential-system concept have been listed. Conclusions. The unity of diagnostic and corrective actions of the concept, which is provided by their internal phenomenology, has been substantiated. It has been proved that the focus and mechanism of reorganization of the existential-system concept is finding paradoxical meanings and paradoxical confrontation with oneself, with self-identity and the world that the client created for himself. It is determined that the existential-system concept is a trans-theoretical psychological system of providing the process of semantic dynamics of personality consciousness. Its goal is the maximum living and "fulfillment" of a life with authentic attitudes, freedom and responsibility for existence and the world.

Key words: trans-theoretical approach, self-attribution, existence, challenges, meaning, diagnostics.

\section{Introduction}

The long process of accumulation of psychological ideas, acquired and tested discoveries, consistent and progressive accumulation of the semantic extent of knowledge led to the priority of monoideology with delimitation and separation of psychological directions. The various worlds of psychological concepts are uniquely created by unrivaled authors. These are theoretical and methodological prisms which outlined the framework for the spread of their own proclaimed truths and insurmountable boundaries for the postulates of other theoretical and practical schools. The consistent movement of the development of psychological science is the transition from experimental (explanatory) to experiential (functional, understanding, phenomenological) paradigm. It is aimed at capturing real life expe- концепту, яким оперує психолог-фахівець. Побудована наочна модель теоретичного конструкту екзистенціально-системного підходу, яка відбиває репрезентації клієнта. Запропонована змістовна схема взаємозв'язків і взаємодії онтологічних репрезентацій восьми ракурсів "співвіднесення зі світом" як дії знаходження смислу. Обгрунтовано взаємодоповнення діагностичних підходів та запропонована схема зв'язку елементів діагностично-корекційних підходів екзистенціально-системного концепту реорганізації “картини світу” особистості: екзистенціального, системного моделювання та психодрами, проективного, психосемантичного, бодинамічного і трансперсонального. Перераховано технічні прийоми, які предметно вимальовують методичний потенціал екзистенціально-системного концепту. Висновки. Обгрунтовано єдність діагностичних та корекційних дій концепту, яка забезпечується їх внутрішньою феноменологією. Доведено, що фокусом та механізмом реорганізації екзистенціально-системного концепту виступає знаходження парадоксальних смислів та парадоксальна конфронтація із самим собою, зі своєю власною ідентичністю і тим світом, який клієнт створив для себе. Визначено, що екзистенціально-системний концепт - це транстеоретична психологічна система забезпечення процесу смислової динаміки свідомості особистості з метою максимального проживання та “виконання" свого життя з автентичними установками, свободою і відповідальністю щодо власної екзистенції та світу.

Ключові слова: транстеоретичний підхід, самовіднесення, екзистенція, виклики, смисл, діагностика.

\section{Вступ}

Тривалий процес накопичення психологічних ідей, здобутих і перевірених відкриттів, послідовноїй поступальної акумуляції змістового об’єму знань приводив до пріоритету моноідеології із розмежуванням та сепарацією психологічних напрямів. Унікально створені неперевершеними авторами різноманітні світи психологічних концепцій- це теоретичнійметодологічні призми, які, водночас, окреслювалирамки розповсюдження власних проголошених істин і непереборні границі для постулатів інших теоретичних і практичних шкіл. Послідовний рух розвитку психологічної науки полягає у переході від експериментальної (пояснювальної) до експірієнтальної (функціональної, розуміючої, феноменологічної) парадигми, яка спрямована на схоплення 
Conceptualization of the existential-system model of reorganization of the "worldview" of the personality: the introduction of ontological dominants

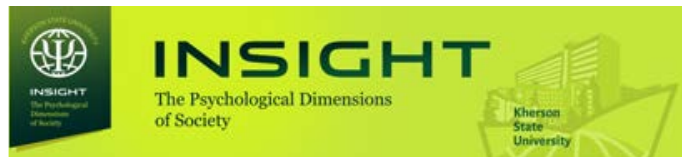

riences, studying and explaining their dynamics, constructing the ontological field of the individual life and determining the means of its existence (Leontiev, 2018). Comprehensive methodology of patterns' analysis, mechanisms and variability of the processes of dynamics of the complex system, which is a person, actualizes the need for integrated (Kovalev, 2001; Tsapkin, 2004), multi-theoretical and eclectic-integrative (Zeig, Munion, 2000) or trans-theoretical (Prochazka, Norcross, 2007) convergence of existing psychological systems.

The trans-theoretical existential-system concept is based on the principle of convergence of multidirectional paradigmatic approaches in order to create an effective construct of assistance and implementation of changes. The existential-system model is the result of the application of a "polyphonic" approach to the reorganization of the subjective "worldview" of the individual in the "polyphony" context of psychological systems of assistance to clients in psychological practice.

Substantiation of the complex methodology of the existential-system concept focuses on the solution of the triple task:

1) Construction of the multifaceted plane of the existential-system approach on the basis of integrative unity, synergetic and dynamic approaches. It combines ontological, system, genetic, contextual and functional aspects of the procedural action of the reorganization of the semantic architectonics of personality consciousness;

2) Outlining the ontological dominants of the existential-system model in order to ensure the theoretical organization of the concept, constructing a scheme of concepts' interconnection, outlining the general picture of research and reorganization of the personality "worldview" as a subjective semantic model of objective reality;

3) Explanation of the hypothetical mechanism and procedural logic of the reorganization action of the existential-system concept, forecasting the trends of given changes and compilation of the operational algorithm of the change process.

The first step was the plane design of the existential-system model, which consists of existential analysis, theory of dynamic systems, individual and transpersonal psychology, psychodrama, system modeling and some practical branches реальних життєвих переживань, вивчення та пояснення їх динаміки, на конструювання онтологічного поля життя людини та визначення засобів іï екзистенції (Леонтьєв, 2018). Комплексна методологія аналізу закономірностей, механізмів та багато варіативності процесів динаміки складної системи, якою $\epsilon$ людина, актуалізує необхідність інтегрованої (Ковальов, 2001; Цапкін, 2004), мультитеоретичної й еклектико-інтегративної (Зейг, Мьюніон, 2000) або транстеоретичної (Прохазка, Норкросс, 2007) конвергенції існуючих психологічних систем.

Транс теоретичний екзистенціально-системний концепт базується на засаді сходження різноспрямованих парадигмальних підходів 3 метою створення дійового конструкту допомоги та здійснення змін. Екзистенціально-системна модель $є$ результатом застосування "поліфонічного" підходу до реорганізації суб'єктивної “картини світу” особистості в умовах “багатоголосся” психологічних систем надання допомоги клієнтам у психологічний практиці.

Обгрунтування комплексної методології екзистенціально-системного концепту зосереджується на вирішенні триєдиного завдання:

на побудові на засадах інтегративної єдності, синергетичного та динамічного підходів багатопланової площини екзистенціально-системного підходу, яка поєднує онтологічний, системний, генетичний, контекстний та функціональний аспекти процесуальної дії реорганізації смислової архітектоніки свідомості особистості;

на окресленні онтологічних домінант екзистенціально-системної моделі 3 метою забезпечення теоретичної організації концепту, конструювання схеми взаємозв'язку понять, окреслення загальної картини дослідження та реорганізації “картини світу” особистості як суб’єктивної смислової моделі об'єктивної реальності;

на поясненні гіпотетичного механізму та процесуальної логіки реорганізаційної дії екзистенціально-системного концепту, прогнозуванні тенденцій заданих ним змін та складанні операційного алгоритмупроцесу змін.

Перший крок полягав у конструюванні площини екзистенціально-системної моделі, 
such as decoding experience, neurological levels, and holotropic breath work. The constructed plane of the trans-theoretical concept highlights the complementarities of its elements (initial paradigms), but, at the same time, it preserves their conceptual differences and unique theoretical and pragmatic value in the general psychotherapeutic and psycho counseling system of psychology. The logic of choosing these elements of the concept was set by theoretical (regarding the content) and practical (in terms of means) opportunities to make a unique and an indispensable contribution to the analysis of all possible aspects of "correlation with the world". These elements show a fundamental diversity but, at the same time, the essential unity of the existential-system concept, the ability to influence the dynamics of individual meanings, in particular, the process of intentional creation of meaning and the basis of self identity and the acquisition of a certain life position as a source of meaning in a life situation.

The next step provides the conceptualization of the existential-system approach by means of methodological procedure of introduction of key ontological representations and their design into a holistic system.

\section{The purpose and the research issue}

The purpose of the article is to highlight the essence and logic of the connection of ontological dominants of the existential-systemic concept, within which the conditions, processes and techniques of diagnostics and reorganization of the "worldview" of a personality are made out.

\section{Methodology}

The procedure of theoretical and methodological research ensures the achievement of semantic, structural and organizational results of the analysis of key concepts of the existential-system approach to the reorganization of the semantic architectonics of the consciousness of personality and consists of such elements:

- spectral approach, which determines the effect of theoretical and methodical complementarity of the elements of the existentialsystem construct regarding the expected result (Tsapkin, 2004);

- structural, which consists in determining the isomorphism, interaction and coherence of the concepts of the original paradigmatic systems in creating a new concept; яка складається з екзистенціального аналізу, теорії динамічних систем, індивідуальної й трансперсональної психології, психодрами, системного моделювання та окремих практичних розгалужень - декодування досвіду, нейрологічних рівнів, холотропного дихання. Вибудована площина транстеоретичного концепту висвічує взаємодоповнення між його елементами (вихідними парадигмами), але, в той же час, зберігає їх концептуальні розбіжності та унікальну теоретичну і прагматичну цінність в загальній психотерапевтичній і психолого-консультативній системі психології. Логіка вибору означених елементів концепту задавалась теоретичними (відносно змісту) і практичними (відносно засобів) можливостями кожного $з$ них надати унікальний і незамінний внесок в аналіз всіх можливих ракурсів “співвіднесення зі світом". Означені елементи проявляють фундаментальне різноманіття але, водночас, і суттєву єдність екзистенціально-системного концепту впливати на процес динаміки смислів особистості, зокрема, на процес інтенціального створення смислу і основи власної ідентичності та на придбання певної життєвої позиції як джерела смислу в життєвій ситуації.

Наступний крок передбачає концептуалізацію екзистенціально-системного підходу за допомогою методологічної процедури введення ключових онтологічних уявлень та оформлення їх у цілісну систему.

Мета статті - висвітити сутність та логіку зв'язку онтологічних домінант екзистенціально-системного концепту, в межах якого оформлюються умови, процеси і технічні прийоми діагностики та реорганізації “картини світу" особистості.

Методологія. Процедура теоретико-методологічного дослідження забезпечує досягнення змістового і структурно-організаційного результатів аналізу ключових понять екзистенціально-системного підходу реорганізації смислової архітектоніки свідомості особистості та складається із:

- спектрального підходу,щозумовлює дію теоретико-методичної додатковості елементів екзистенціально-системного конструкту щодо очікуваного результату (Цапкін, 2004);

- структурного, який полягає у визначенні ізоморфізму, взаємодії та узгодженості понять 
Conceptualization of the existential-system model of reorganization of the "worldview" of the personality: the introduction of ontological dominants

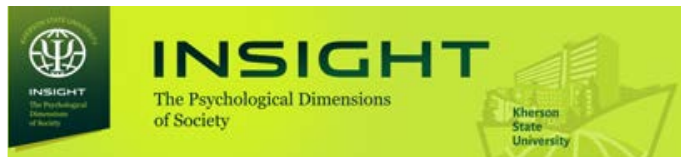

- semiotic approach, which provides research and analysis of patterns of reorganization process of change.

\section{Results and discussion}

Conceptualization of the existential-system approach involves a substantiation of a number of provisions and the implementation of sequential actions, such as:

1) the implementation of the conceptual operationalization of the ontological dominants of the integrative multifaceted coordinate plane of the existential-system concept;

2) construction of the scheme (model) of connection of basic concepts that reflect the trends of change and allow producing hypotheses about nature of their relationship and make out the functional principles of the approach;

3) construction of classification of diagnostic methods for studying "worldview" of the personality;

4) substantiation of reorganization process of the semantic architectonics of personality consciousness.

We are based on the key assumption that all the variety of clients' requests are contained in the space of their existential reality, with a fragment of which they relate and which affects them significantly. Existential reality is vitally determining and vitally forming. Therefore, a person's life is determined by its "correlation with the world". It can be considered in eight different perspectives: "I am"; "This is me"; "These are My experiences"; "These are My thoughts"; "This is what I do"; "This is My present life"; "This is My past"; "These are My ideas about the future". The process of "correlation with the world" is an act and the result of one's own phenomenological perception of a person, or it is an act of directed psychological action under the condition of seeking help. The ultimate consequence of "correlation with the world" is finding the meaning that currently determines the quality and content of human existence and causes self-determination, reflexive processes, internal dialogue and, consequently, the dynamics in the architectonics of its meanings. Therefore, it is desirable to consider the "Correlation with the world" in the format of the ontological field, as a generalized action of revealing the meanings of the personality in the process of constructing a "worldview" (Fig. 1). вихідних парадигмальних систем при створенні нового концепту;

- семіотичногопідходу, котрий забезпечує дослідження та аналіз закономірностей реорганізаційного процесу змін.

Результати і дискусія. Концептуалізація екзистенціально-системного підходу передбачає обгрунтування низки положень та виконання послідовних дій, а саме:

1) здійснення понятійної операціоналізації онтологічних домінант інтегративної багатопланової координатної площини екзистенціально-системного концепту;

2) конструювання схеми (моделі) зв'язку базових понять, що відбивають тенденції змін та дозволяють продукувати гіпотези про природу, характер їх взаємозв'язку і оформлюють функціональні засади підходу;

3) побудова класифікації методів діагностики “картини світу” особистості;

4) обгрунтування процесуреорганізації смислової архітектоніки свідомості особистості.

Ми виходимо з ключового припущення, що все різноманіття запитів клієнтів міститься в просторі їх екзистенціальної дійсності, 3 фрагментом якої вони себе співвідносять і який значуще на них впливає. Екзистенціальна дійсність $є$ життєво визначальною та життєво формуючою, а тому життя людини зумовлюється їі “співвіднесенням зі світом", яке можна розглядати у восьми різних ракурсах: "Я $є$ "; "це $\epsilon$ Я”; “це Мої переживання”; “це Мої думки”; “це Я роблю”; “це Моє життя зараз"; "це Моє минуле"; “це Мої уявлення про майбутнє”. Сам процес “співвіднесення зі світом" є актом і результатом або власного феноменологічного сприйняття людини, або, за умови звертання за допомогою, спрямованої психологічної дії. Кінцевим наслідком "співвіднесення зі світом" виступає знаходження того смислу, який на даний момент зумовлює якість та зміст екзистенції людини і викликає самодетермінацію, рефлексивні процеси, внутрішній діалог та, як наслідок, динаміку в архітектоніці їі смислів. Тому “співвіднесення зі світом", як генералізовану дію виявлення смислів особистості у процесі конструювання “картини світу”, бажано розглянутиу форматі онтологічногополя (рис. 1). 

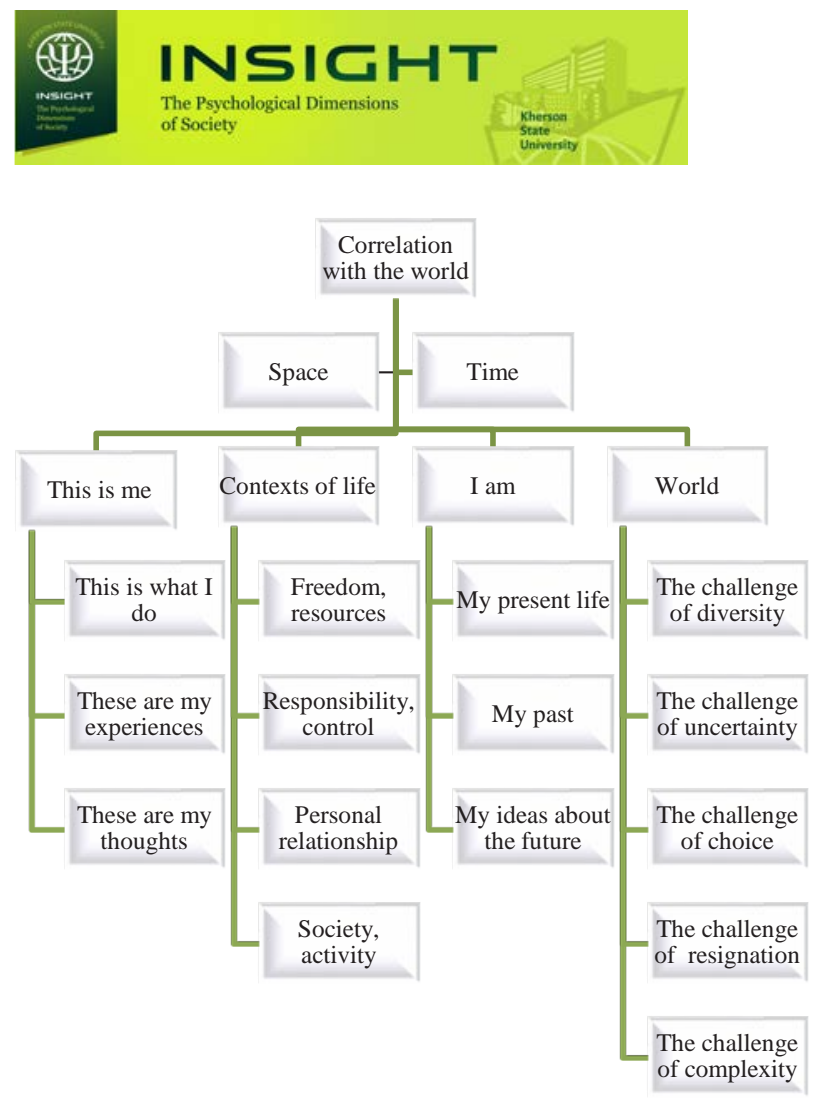

Figure 1. The ontological field of the semantic model of the world of personality

Рис. 1. Онтологічне поле смислової моделі світу особистості

This field outlines a set of five possible projections of the existential-systemic study of human existential reality, which is reflected in the specifics of its semantic model of the world and creates an original "worldview".

The first projection is a measurement of "presence-openness" and deployment of the paradox of meanings in the self sense and awareness of their essence in space and time. A. H. Almaas pays attention to the difference between two aspects of essence such as: the sense of presence "This is me" and the sense of transcendent "I am", which is based on the experience of openness of time and space (Almaas, 1996). "I am" is a circle-centric dominant, which determines the synergistic balance of energy of the past and future in relation to the present. It is considered as a potential opportunity to become yourself, to give yourself your life. "I am" covers the understanding of self experience and attitude to it, the orientation of ideas about the future and the authentic attitude to oneself in the present. "I am" defines the "color" of the flow in which life takes place and a sense of naturalness and urgency of the causes that determine this "color". It is an understanding of one's own means

\section{Kalishchuk Svitlana}

Означене поле окреслює множину п'яти можливих проекцій екзистенціально-системного дослідження екзистенціальної дійсності людини, якавідбивається успецифіціїі смислової моделі світу та вимальовуєсамобутню“картину світу".

Перша проекція - це вимір “присутності-відкритості” і розгортання парадоксальності смислів у відчутті самості та усвідомлення своєї сутності у просторі й часі. А. Х. Алмаас звертає увагу на відмінність між двома аспектами сутності: почуттям присутності “це Я $\epsilon$ " та почуттям трансцендентного “Я $\epsilon$ ", яке спирається на досвід відкритості часу та простору (Алмаас, 1996). “Я є” виступає коло-центричною домінантою, яка зумовлює синергетичний баланс енергетики минулого та майбутнього щодо сьогодення і розглядається в якості потенційної можливості стати собою, дати собі своє життя. “Я є” охоплює розуміння свого досвіду і відношення до нього, спрямованість уявлень про майбутнє та автентичне ставлення до себе зараз у теперішньому часі. "Я $\epsilon$ " визначає "колір" потоку, в якому здійснюється життя івідчуття природності та невідкладності тих причин, які викликають цей “колір”. Це розуміння власного засобу осягнення світу і джерел власної повноти й ефективності, це зустріч із собою і своєю унікальністю.

Сутність “це $€$ Я" окреслює характер і модальність активності особистості, ступінь свободи і відповідальності щодо власних проявів ментального та дієвого плану в різних контекстах життя: в усвідомлені власних ресурсів, у контролі внутрішніх та зовнішніх проявів, в особистих ставленнях та в якостях власного рольового набору в соціумі. “Це $є$ Я” складається з відчуттів, сприйняття, спонукань, емоцій, символів, концепцій, правил та логіки. Поняттями, що iï оформлюють виступають: психологічний зміст емоційних станів, базові емоційні реакції: страх, гнів, сором, відраза, інтерес, подив, радість, сум; відповідніемоціям програми дій: уникнення, руйнування, приєднання, відторгнення, вивчення, переключення, повторення, прохання про допомогу; звичні патерни думок”, наприклад: “Хто мені скаже який я?”, “Все що я роблю повинно бути бездоганним”, “Мені ніхто не допоможе”, "Мені не цікаво із собою”, “Я гублю багато можливостей”, “Я вже давно не задоволений 
Conceptualization of the existential-system model of reorganization of the "worldview" of the personality: the introduction of ontological dominants

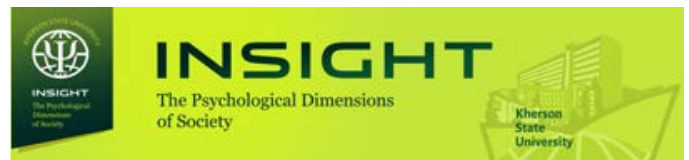

of comprehension of the world and sources of a self completeness and efficiency. It is a meeting with yourself and your uniqueness.

The essence of "This is me" outlines the nature and modality of personal activity, the degree of freedom and responsibility for own manifestations of mental and effective plan in different contexts of life: awareness of self resources, control of internal and external manifestations, personal attitudes and qualities of self role set in society. "This is me" consists of feelings, perceptions, motivations, emotions, symbols, concepts, rules and logic. The concepts that create it are: the psychological content of emotional states, basic emotional reactions: fear, anger, shame, disgust, interest, surprise, joy, sadness; programs of actions that correspond to emotions: avoidance, destruction, accession, rejection, study, switching, repetition, request for help; familiar patterns of thoughts, for example: "Who will tell me what I am?", "Everything I do must be perfect", "No one will help me", "I'm not interested in myself", "I'm losing a lot of opportunities", "I have not been satisfied for a long time with what is happening to me", "I have to control everything", "I don't trust others", "I can't handle the situation," "I'm not accepted," and so on. In general, "This is me" is determined by "crystallized" patterns of behavior, the means of coding self experience, the hierarchy of introjected beliefs, the environment, the qualitative composition of the systems to which the individual belongs, the dynamics of the formation of own values, which are an attribute of the perceived existential fragment of reality.

The second projection is the multiplicity of manifestations of the world's "challenges". Challenges of diversity (for example: own "sub personal" manifestations, emotional reactions, interests, habits, external reactions and situations); challenges of uncertainty (future, actions and attitudes of another person, unpredictability of events); challenges of choice (alternative or multivariate choice of goals, situations, life options, partners); challenges of resignation (lack of opportunity to choose and influence the circumstances) and challenges of complexity (inclusion and active involvement of intellectual, emotional or physical effort). The challenges of the world are the channels of tension spread. They start the processes of "self-attribution" and active overcoming of "environmental resistance" through the discov- тим, що зі мною діється”, “Я повинен все контролювати”, “Я не довіряю іншим”, “Я не можу впоратися із ситуацією", "Мене не приймають" тощо. В цілому, "це $є$ Я" зумовлюється "кристалізованими" патернами поведінки, засобом кодування власного досвіду, ієрархією інтроєктних переконань, оточуючою середою, якісним складом систем, до яких належить індивід, динамікою формування власних цінностей, які виступають атрибутомусвідомленого екзистенціального фрагменту дійсності.

Друга проекція - це множинність проявів “викликів" світу. Виклики різноманітності (наприклад: власних "субособистісних" проявів, емоційних відреагувань, інтересів, звичок, зовнішніх реакцій та ситуацій); невизначеності (майбутнього, дій і ставлень іншої людини, непередбачуваності подій); вибору (альтернативного чи багатоваріативного вибору цілей, ситуацій, варіантів життя, партнерів); резигнації (за умови відсутності можливості вибору і впливу на обставини) та складності (включення і активне задіяння інтелектуальних, емоційних чи фізичних зусиль). Виклики світу - це канали розповсюдження напруги, що вмикають процеси “самовіднесення" і активного переборення "опору середовища" через відкриття смислів. Прийняття життєвих викликів виступає спонтанною, визначально притаманною активністю, що посилює індивіда, робить його експансивним i, одночасно, спрямовує на ускладнення і розвиток (Максименко, 2006).

Третя проекція - це окреслення понятійного змісту екзистенціально-системного концепту. В якості ключових понять його теоретичного оформлення виступають:

- "світ" як простір і час екзистенції людини, матеріальні та енергетичні ресурси ії життя;

- "свідомість" - індивідуальна система створення образу світу, що дозволяє людині самовизначатися в реальному світі, моделюючи все різноманіття оточуючої дійсності та активно впливаючи на неї, створюючи безліч суб'єктивних світів, які у кожному окремому випадку базуються на індивідуально-емпіричному досвіді людини унікально репрезентувати зовнішній об'єктивний світ для себе (Каліщук, 2020б);

- "картина світу" - системна особистісна модель, багатошарова конструкція суб’єктивних образів реального світу та смислових 
ery of meanings. Acceptance of life challenges is a spontaneous, definitely inherent activity that strengthens the individual, makes him expansive and leads to complications and development at the same time (Maksimenko, 2006).

The third projection is an outlining the conceptual content of the existential-system concept. The key concepts of its theoretical design are:

- "world" as the space and time of human existence, material and energy resources of a life;

- "consciousness" is an individual system of creating an image of the world that allows a person to self-determine in the real world. It is due to the modeling of all the diversity of the surrounding reality and active influence on it, creating many subjective worlds. They are based on the individual-empirical experience of a person to represent the external objective world for himself uniquely (Kalishchuk, 2020b);

- "worldview" is a system personal model, a multilayered construction of subjective images of the real world and semantic connections between them, the integrity of the paraphernal generalized pole of experiences, which creates a semantic model of self and the world (Kalishchuk, 2020a);

- "meaning" is "a unit of analysis of the mental, an intentional experience, a noematic correlate, the meaning of the mental" (Agafonov, 2003: 93), which opens in determining the relationship between two (or more) elements of the system;

- "system" is a set of objects and connections between them, which create and maintain space for the realization of "belonging" of each objects, causing repetitive interactions;

- "semantic architectonics of consciousness" is a multicomponent semantic construction of the mental. It is determined by the process of understanding of its own "text" by the consciousness, by constructing meanings of a particular event through relation to it. It is characterized by "recurrence", development of one's own meanings as a text due to the induction of variable interpretation of previously discovered meanings;

- "ideas, experiences, thoughts". Their semiotics (signified and signifier) determines the conventional correlates of meaning formation due to the fact that "we become the stories we tell" (Kibed, Shparrer, 2014: 12);

- "reorganization" is the process of interaction with the environment through repetitive pat- зв'язків між ними, цілісність парафернального узагальненого полюсу переживань, що створює смислову модель себе та світу (Каліщук, 2020a);

- "смисл" - "одиниця аналізу психічного, інтенціальнепереживання, ноематичний корелят, зміст психічного" (Агафонов, 2003: 93), який відкривається у визначеннізв'язку між двома (та більше) елементами системи;

- “система" - сукупність об'єктів і зв'язків між ними, які створюють й утримують простір для реалізації “приналежності" кожного з її об’єктів, зумовлюючи повторювальні (автопоезні) взаємодії;

- “смислова архітектоніка свідомості" - багатокомпонентна смислова конструкція психічного, яка детермінується процесом розуміння свідомістю власного “тексту”, конструюванням смислів окремої події через відношення до неї, характеризується "реккуренцією”, розвитком власних значень як тексту за рахунок індукування варіативного інтерпретування відкритих раніше смислів;

- “уявлення, переживання, думки" - їх семіотика (означаюче та означуване)зумовлює конвенціональні кореляти смислоутворення в силу того, що "ми перетворюємся в ті історії, які розповідаємо" (Кібед, Шпаррер, 2014: 12);

- "реорганізація" - процес взаємодії з оточуючим середовищем через повторювальні патерни "співвіднесення зі світом" та самовіднесення, кожен з яких запускає структурні зміни в системі (Варела, 1995);

- "самовіднесення" - рефлексивне самоусвідомлення як безперервний процес перетворення, динаміки та розвитку особистості, хід ії̈ життя, що здійснюється через переживання континууму станів та створення смислового поля, організованого зв'язками відповідного контексту.

Означені базові поняття являють собою внутрішній простір психологічного ладу екзистенціально-системного концепту, яким оперує психолог-фахівець.

Наочна модель теоретичного конструкту екзистенціально-системного підходу, який наповнюється репрезентаціями клієнта, може бути представлена у формі трикутної піраміди (рис. 2).

Елементи піраміди (вершина, кути, ребра, основа, висота) розкривають структуру 
Conceptualization of the existential-system model of reorganization of the "worldview" of the personality: the introduction of ontological dominants

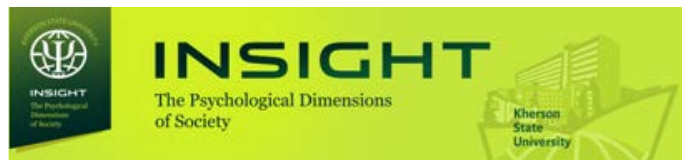

terns of "correlation with the world" and self-attribution, each of them triggers structural changes in the system (Varela, 1995);

- "self-attribution" is a reflexive self-awareness as a continuous process of transformation, dynamics and development of the personality. It is the course of a life, which is carried out through experiencing a continuum of states and creating a semantic field organized by the connections of the relevant context.

These basic concepts represent the internal space of the psychological structure of the existential-system concept, which a psychologist-specialist operates.

The visual model of the theoretical construct of the existential-system approach, which is filled with client's representations, can be presented in the form of a triangular pyramid (Fig. 2).

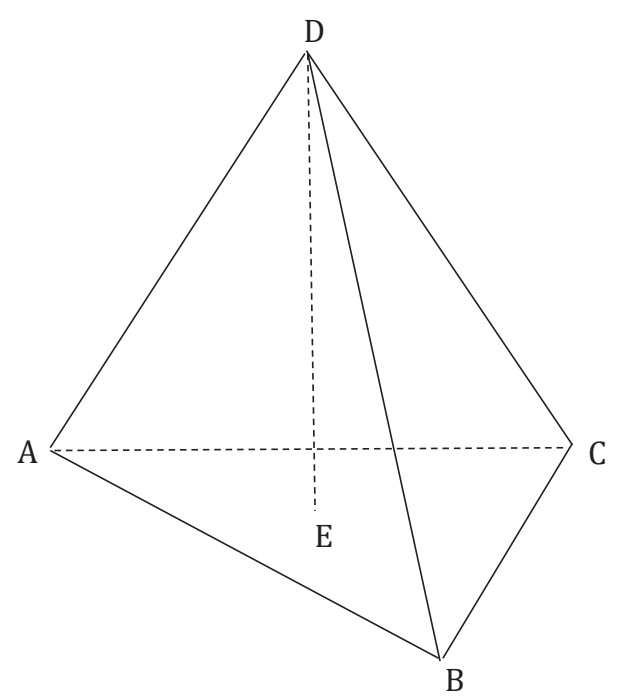

Figure 2. The format of the connections of ontological representations of "correlation with the world" as an action of finding meaning

Рис. 2. Формат зв'язків онтологічних репрезентацій “співвіднесення зі світом" як дії знаходження смислу

Elements of the pyramid (top, corners, ribs, base, and height) reveal the structure of relationships of ontological elements of the existential-system concept, namely:

- top D - "Meaning" (Why? What does it mean for me? How does it change me? How does it complement me? How does it enrich me?);

- LA - "Sociocultural context, past, experience, beliefs, I must" (Why? How will it be right?); взаємозв'язків онтологічних елементів екзистенціально-системного концепту, а саме: вершина Д - “Смисл” (Навіщо? Що це для мене значить? Як це мене змінює? Як це мене доповнює? Як збагачує?);

LA - “Соціально-культурний контекст, минуле, досвід, переконання, Я повинен" (Чому? Як правильно?);

டB - “Феноменологія життя, моє життя зараз, Я можу, теперішній час" (Як? Чи можу це? Де?);

டC - "Мої уявлення про майбутнє, ідеї, перспективи, Я хочу" (Куди йти? Чи хочу цього?);

АД - “Це мої думки, звичні (типові) патерни розуміння” (Як інтерпретую? Про що міркую?);

ВД - “Це мої переживання, це мої звичні (типові) емоційні патерни” (Що відчуваю? Що мені треба? Що є моєю необхідністю зараз?);

СД - “Це я роблю, звичні поведінкові патерни” (Що я роблю? Як я це роблю?);

основа АВС - “Це є Я, ідентичність” (Хто Я?);

висота ДЕ - “Я Є” (мої ресурсні стани, моє “призначення" в системах);

АВ - “Мої системи, простір, об'єкти" (Хто? Що?);

AC - “Виклики, кризи” (Що змінилося? Чи $\epsilon$ у мене тривога? Чи був у мене вибір? Що я відчуваю: сумніви чи рішучість?);

ВC - “Переоцінка, цінності” (Чому це важливо для мене?).

Означена система взаємозв'язків конструктів екзистенціально-системного концепту оформлює функціональні засади підходу, відбиваєспрямованість та вектори рівнів, процесів і стадій змінв об'ємній координатній площині процесу реорганізації смислової архітектоніки свідомості особистості, забезпечуючи відкриття смислів на чотирьох рівнях екзистенції людини: “зі світом як соціально-культурним контекстом та досвідом”, “із цінностями власного життям, власна феноменологія", з “це є Я" - власною ідентичністю та зі своїм “перспективним майбутнім".

Змістовна схема зв'язків теоретичних конструктів екзистенціально-системного концепту зображена на рис.3.

Четвертапроекція екзистенціально-системного концепту відбиває класифікацію методів діагностики смислової моделі світу особистості. Об'єктивно заданою методичною засадою діагностики, виступає інтрапсихічна 


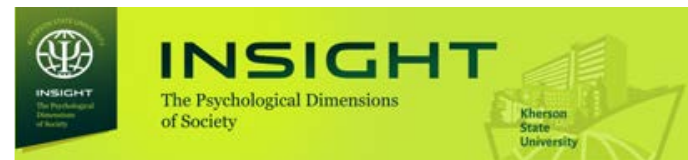

- LB - "Phenomenology of life, my life now, I can, the present" (How? Can I do it? Where?);

- LC - "My ideas about the future, ideas, prospects, I want" (Where should I go? Do I want it?);

- $\mathrm{AD}$ - "These are my thoughts, the usual (typical) patterns of understanding" (How do I interpret? What do I think?);

- BD - "These are my experiences, these are my usual (typical) emotional patterns" (What do I feel? What do I need? What do I need now?);

- CD - "This is what I do, habitual behavioral patterns" (What am I doing? How am I doing this?);

- the base of ABC - "This is me, identity" (Who am I?);

- height DE - "I am" (my resource states, my "purpose" in the systems); What?);

- AB - "My systems, space, objects" (Who?

- AC - "Challenges, crises" (What has changed? Do I have anxiety? Did I have a choice? What do I feel: doubts or determination?);

- BC - "Revaluation, values" (Why is this important to me?).

This system of interrelations of constructs of the existential-system concept forms functional bases of the approach. It reflects a direction and vectors of levels, processes and stages of changes in the three-dimensional coordinate plane of the process of reorganization of semantic architectonics of personality consciousness. This provides the discovery of meanings on four levels of human existence: "with the world as a socio-cultural context and experience", "with the values of one's own life and own phenomenology", with "this is me" - self identity and with one's "perspective future".

The meaningful scheme of connections of theoretical constructs of the existential-system concept is shown in Figure 3.

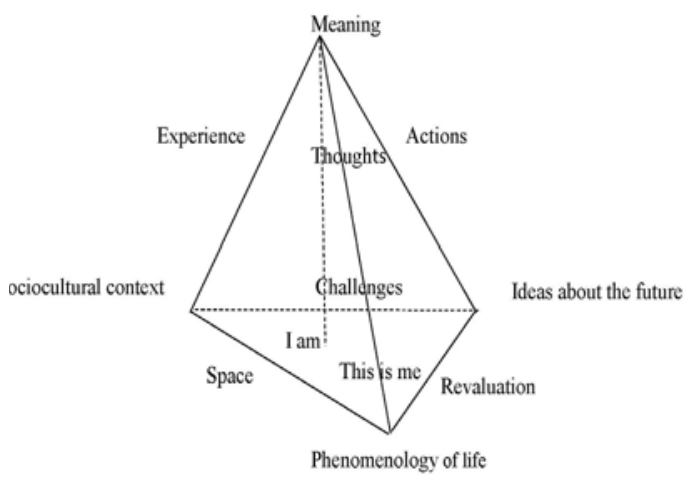

Figure 3. Meaningful scheme of relationships and interaction of ontological representations of "correlation with the world" as an action of finding meaning

Рис. 3. Змістовна схема взаємозв'язків і взаємодії онтологічних репрезентацій "співвіднесення зі світом" як дії знаходження смислу

\section{Kalishchuk Svitlana}

спрямованість, занурення у рефлексивні процеси з метою відчути власні потреби, усвідомити внутрішній діалог, самовизначитись у модальностях власної необхідності ("мені це треба" і “я це хочу"), розкрити ресурсний стан компліментарності зі світом та дізнатися про стани свого типового реагування на події, базові емоції, які є тлом життєдіяльності та життєтворчості. Обгрунтування технології діагностики “картини світу” спирається на три вихідні припущення, а саме:

- методи такої технології повинні проявляти дійсність як текст через дію розуміння;

- “картина світу" припускає наявність узагальнено-типової схематичної іiї будови, універсальної для кожного індивідуального випадку, що дозволяє профілювати та верифікувати отримані дані;

- система, в якій функціонує досліджуваний, виступає одночасно фоном прояву, текстом, який описує його екзистенції та детермінантою подальшого конструювання “картини світу”.

Враховуючи, що пошуковим полем діагностики смислової архітектоніки є інтрапсихічна реальність, простір середини себе,центру суб'єктності людини, топредмет діагностикискладають:

1) звичні (типові) стилі реагування;

2) “кристалізовані” патерни поведінки;

3) емоційні та когнітивні протилежності;

4) тілесні деструктивні відчуття, симптом як специфічний текст, що репрезентує зміст внутрішнього конфлікту;

5) якість та модальність зв'язків, що встановлені в системі між її елементами;

6) смислова карта суб'єктивних уявлень про дійсність - "картина світу”, зумовлена внутрішнім досвідом людини.

Означені вище положення зумовлюють i внутрішню логіку діагностики “картини світу" особистості, й алгоритм зовнішніх операцій, які реалізуються за допомогою:

- проективногопідходу (“Самий ранній дитячий спомин” А. Адлера; методика Ф. Фідлера "Тип установки щодо інших"; методика "Мій світ" - модифікована методика “Хто Я?" М. Куна та Т. Макпартленда; Лист-потік 10 хвилин “Жити - це...”; ранжування в присутності спостерігача-про файл ера цінностей з посиленим емоційним компонентом для визначення крапок аттракції 
Conceptualization of the existential-system model of reorganization of the "worldview" of the personality: the introduction of ontological dominants

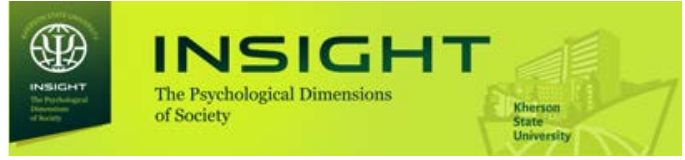

The fourth projection of the existential-system concept reflects the classification of methods of diagnosing the semantic model of the world of personality. Objectively given methodological basis of diagnosis are intrapsychic orientation, immersion in reflexive processes in order to feel own needs, to realize internal dialogue, to self-determine in modularity of one's own need ("I need it" and "I want it"), to reveal the resource state of complementarity with the world and to learn about the states of your typical reaction to events, basic emotions, which are the background of life and life creation. Substantiation of the technology of diagnostics of the "worldview" is based on three initial assumptions, namely:

- methods of such technology must manifest reality as a text through the action of understanding;

- "worldview" implies the presence of its generalized-typical schematic structure, universal for each individual case. It allows profiling and verify the obtained data;

- the system in which the subject operates is both the background of the manifestation, the text that describes its existence and the determinant of further construction of the "worldview".

Since the search field for the diagnosis of semantic architectonics is an intrapsychic reality, the space of the middle of a self, the center of human subjectivity, so the subjects of diagnosis are:

1) usual (typical) response styles;

2) "crystallized" patterns of behavior;

3) emotional and cognitive opposites;

4) bodily destructive feelings, a symptom as a specific text representing the content of internal conflict;

5) the quality and modality of connections established in the system between its elements;

6) semantic map of subjective ideas about reality - "worldview", which is determined by the inner experience of a person.

These provisions determine the internal logic of the diagnosis of the "worldview" of a personality, and the algorithms of external operations, which are realized by means of:

- projective approach ("The earliest childhood memory" by A. Adler; F. Fiedler's method "Type of attitude towards others"; method "My world" - a modified method "Who am I?" by M. Kuhn and T. McPartland; Letter-flow 10 minutes "To live is..."; ranking of values with an enhanced emotional component to determine the points of attraction of the subject's system) that is car- системи досліджуваного) (Адлер, 1932; Каліщук, 2014);

- психосемантичного підходу (моделювання "семантичних універсалій" "картини світу",семантичного аналізу порушень смислових утворень, визначення міри заповнення семантичного вакууму базових категорійвласної екзистенції смисловими відкриттями; опис ситуацій, станів та ставлень; вільна класифікація; семантичні диференціали; методи особистісних конструктів) (Серкін, 2008);

- екзистенціального підходу ("досвід зустрічі із собою, зі світом й іншими людьми”;"співвіднесення та діалогічний обмін між Я і світом";усвідомлення базових механізмів дії “інтенціальності", “самотворення”, “автентичності", “внутрішньої рівноваги”, “свободи”, “відповідальності”, “трансцендентності”; “варіанти життя" за В. М. Дружиніним; усвідомлення внутрішнього діалогу здійснення переходу від страху реакцій тіла до усвідомлення симптому як порушеного балансу між ваганням і відповідальністю й свободою вибору) (Дружинін, 2010);

- системного моделювання і психодраматичного підходу (моделювання і відреагування ситуацій, що мають вагому емоційну напругу; розпізнавання знайдених дисбалансів; побудова моделей "Я і моє Призначення”; “Я і Свобода"; “Я і Відповідальність"; “Яі Життя”; відкриття парадоксального сенсу при виявленні переважних станів та програм дій, які генерує досліджуваний; “квантовий стрибок"; “віртуальне сканування”; генералізація "Я”; визначення "супер-позиції”; “тріада"; “тетролемма”; квадрат “Да-Нi”; “конфлікт цінностей”; “конфлікт дій”; “вибір"; “контекст станів"; “подорож до глибинної мети”; “баланс між унікальністю і цінністю”, “лінія життя" тощоз метою аналізу складових системи та виявлення неефективного вихідного аттрактору і знаходження тригеру) (Каліщук, 2018);

- бодинамічного підходу ("Новий позитивний імпринтинг народження"з метоювідкриття конденсованого досвіду та фіксованої установки імпринтингу народження як базової крапки біфуркації життя, як фундамент формування емоційних і поведінкових патернівй специфічної емоційної забарвленості 
ried out in the presence of an observer-profiler (Adler, 1932; Kalishchuk, 2014);

- psychosemantic approach (modeling of "semantic universals" of the "worldview", semantic analysis of violations of semantic formations, determining the degree of filling the semantic vacuum of the basic categories of one's own existence with semantic discoveries; description of situations, states and attitudes; free classification; semantic personalities; measuring personality constructs) (Serkin, 2008);

- existential approach ("experience of meeting oneself, the world and other people"; "correlation and dialogical exchange between self and the world"; awareness of the basic mechanisms of action of "intentionality", "self-creation", "authenticity", "inner balance", "freedom", "responsibility", "transcendence"; "life options" by V. M. Druzhinin, awareness of an internal dialogue as the transition from fear of body reactions to awareness of the symptom as a disturbed balance between hesitation, responsibility and freedom of choice) (Druzhinin, 2010);

- system modeling and psychodrama (the following methods are used to analyze the components of the system and identify the inefficient output attractor and find the trigger: modeling and responding to situations that have significant emotional tension; recognition of found imbalances; construction of models "Me and my purpose"; "Me and Freedom"; "Me and Responsibility"; "Me and Life"; discovery of paradoxical meaning in identifying the predominant states and action programs generated by the subject; "quantum leap"; "virtual scanning"; generalization of "I"; definition of "super-position"; "triad"; "tetrolemma"; square "Yes-No"; "values conflict"; "conflict of action"; "choice"; "context of states"; "journey to a deep goal"; "balance between uniqueness and value", "lifeline", etc.) (Kalishchuk, 2018);

- body-dynamic approach "New positive imprinting of birth" in order to discover the condensed experience and fixed attitudes of imprinting birth as a basic point of bifurcation of life, as the foundation of the formation of emotional and behavioral patterns and the specific emotional coloration of the subjective model of reality (Kalishchuk, 2020a);

- transpersonal approach (holotropic breathing according to $\mathrm{S}$. Grof as a means of combining breathing and music. It is a means of energizing and channeling human experiences in order to respond to "emotional rolls" physically and discovering their meanings) (Grof, 2008).

These approaches and techniques objectively outline the methodological potential of the existen- суб'єктивної моделі реальності (Каліщук, 2020a);

$$
\text { - трансперсонального підходу }
$$

(холотропне дихання за С. Грофомяк засіб, що поєднує дихання й музику та є засобом енергетизації й каналізації переживань людини з метою тілесного відреагування “емоційних скалок”та відкриття їх смислів) (Гроф, 2008).

Перераховані підходи і технічні прийоми предметно вимальовують методичний потенціал екзистенціально-системного концепту, дві відмітні риси якого полягають у:

1) можливості "осягнути неосяжність" і змоделювати та "перепрожити" безкінечну кількість простих та складних понять, якими оперує досліджуваний при описі та переживанні своєї екзистенції, охопити багатоплановий світ його почувань, образів, ідей, сфер, ролей, загальних чи конкретних тем, завдань та цілей;

2) одночасній діагностичній та корекційній дії означених підходів та технічних прийомів, що забезпечуєтьсяїх внутрішньою феноменологією, яка задаєсинхронність операцій розширення горизонту бачення себе і контекстів свого життя i, разом з тим, розкриття нових, неусвідомлених раніше можливостей ізнаходження новоз'явлених орієнтирів через знаходження смислу.

Екзистенціально-системний концепт не має обмеженості щодо предмету моделювання та змісту запиту, а тому, дозволяє скласти, кожен раз, мінімально достатню й максимально необхідну "діагностичну програму” i предметно визначити фокус й призму сприйняття досліджуваного (значуща людина, важлива подія особистої істоpiї, ракурс проблеми, симптом, особистісний конструкт, гіпотетичне уявлення тощо) і його континуальні засади (Чому я бачу світ саме так? Що в цьому баченні викликає почуття неузгодженості та парадоксальності?).

На рис. 4 зображено зв'язаність діагностично-корекційних підходів екзистенціально-системного концепту реорганізації смислової моделі світу клієнта.

П’ята проекція охоплює трансформаційні можливості екзистенціально-системного концепту до динаміки смислових утворень, які аргументуються двома вагомими базисами: 
Conceptualization of the existential-system model of reorganization of the "worldview" of the personality: the introduction of ontological dominants

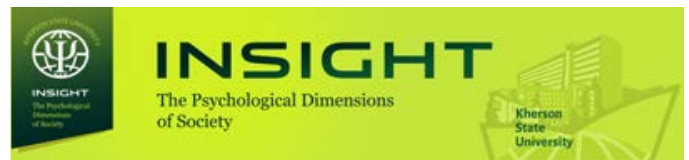

tial-system concept. Their two distinctive features are:

1) the ability to "comprehend the immensity" and model and "relive" an infinite number of simple and complex concepts used by the subject in describing and experiencing his existence; the ability to cover the multifaceted world of person's feelings, images, ideas, areas, roles, general or specific topics, tasks and goals;

2) simultaneous diagnostic and corrective action of these approaches and techniques. They are ensured by their internal phenomenology, which sets the synchronicity of operations to expand the horizons of self-vision, vision of the contexts of a life and, at the same time, to open new, previously unconscious opportunities and to find newly appeared landmarks through finding meaning.

The existential-system concept has no restrictions on the subject of modeling and the content of the request. Therefore, it allows to make the minimum sufficient and the most necessary "diagnostic program" and objectively determine the focus and prism of the subject's perception (significant person, an important event in personal history, a view of the problem, symptom, personal construct, hypothetical idea, etc.) and its continuous principles (Why do I see the world this way? What causes this feeling of inconsistency and paradox?

Figure 4 shows the connection of diagnostic and corrective approaches to the existential-system concept of reorganization of the semantic model of the client's world.

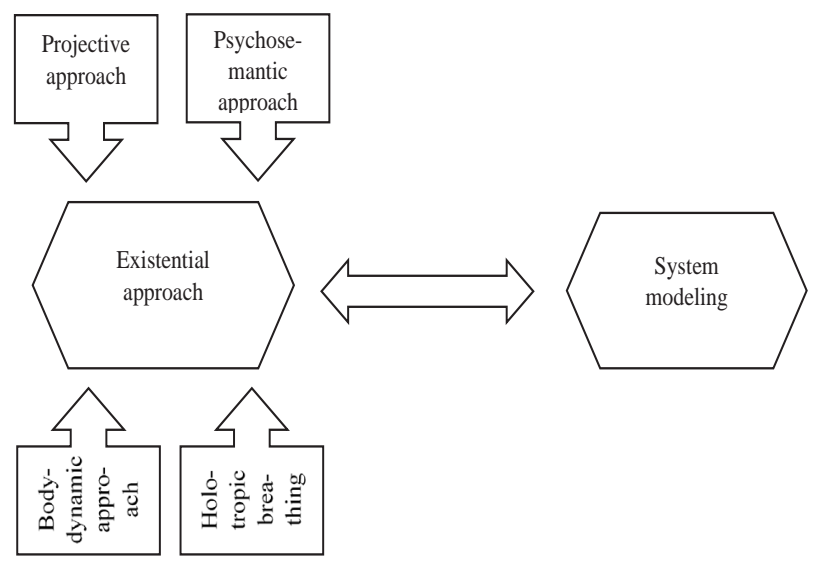

Figure 4. Elements of diagnostic and corrective approaches to the existential-system concept of reorganization of the "worldview" of a personality

Рис. 4. Елементи діагностично-корекційних підходів екзистенціально-системного концепту реорганізації “картини світу” особистості загальною теорією систем (O'Коннор, Макдермотт, 2006) та теорією загально-психологічного перетворення діяльностей та потреб (Братусь, Лішин, 1982). 3 точки зору загальної теорії систем, в екзистенцію людини закладені потенційні засади створювати вільні зв'язки в системі, що актуалізуються наведеними вище методами. Це проявляє одночасно і ресурс для змін, і середовище для реалізації цього ресурсу. Екзистенціально-системний підхід дає можливість вимірювати динамічний стан системи, виявляти важливі елементи системи, модальність та силу зв'язків між об'єктами, проявляти смисл, що система носила в собі як старий і помилковий аттрактор. А крім того, довести систему до крапки біфуркації та запустити новий порядок організації системи через переривання постійно відтворюючих у клієнта зв’язків, ставлень (“урівноважуючий зв'язок”), їх розуміння і усвідомлення. Завершення та зміна зв’язків (“підсилюючий зв'язок”) зменшує можливість повернутися до первісної, звичної форми стабільності системи і цим самим забезпечується перехід на новий рівень функціонування особистості, з новим аттрактором (знайденим смислом), що забезпечуватиме більш перспективніше тяжіння системи до стабілізації. Тому, екзистенціально-системний аналіз відкриває можливості трансформувати стани, виявляти не тільки характер зв'язків між об'єктами, що складають складну систему, але й, одночасно, довести та усвідомити роль та значення множинних комбінацій взаємо-впливових факторів, а саме: елементів системи, переважних станів та зв'язків, що складають систему. А також, визначати причино-наслідкові зв'язки між об'єктами з позиції часу і перейти від фіксації явищ, що відбуваються до розуміння структурних взаємозв'язків, що породжують певні послідовності (патерни) явищ.

Загально-психологічне перетворення діяльностей та потреб змальовує внутрішній механізм створення (знаходження) смислів, який здійснюється відповідно схеми послідовної дії смислоутворення: невизначений, безпредметний потребовий стан (неусвідомлений конфлікт між не прийнятим, витісненим особистісним смислом та потребовим станом) $\rightarrow$ вибір конкретного мотиву-предмету потреби (потребовий стан не усвідомлюється, 
The fifth projection covers the transformational possibilities of the existential-system concept to the dynamics of semantic formations. They are argued by two important bases such as: the general theory of systems (O'Connor, McDermott, 2006) and the theory of general psychological transformation of activities and needs (Bratus, Lishin, 1982). Based on the general theory of systems, there are potential principles in human existence to create free connections in the system. These connections are actualized by the mentioned methods. This shows both a resource for change and an environment for the implementation of this resource. The existential-system approach makes it possible to measure the dynamic state of the system; to identify important elements of the system, modality and strength of connections between objects, to show the meaning that the system carried as an old and false attractor. In addition, it makes possible to bring the system to the point of bifurcation and start a new order of the system organization by interrupting the constantly reproducing client's connections, attitudes ("balancing connection"), their understanding and awareness. Completion and change of connections ("strengthening connection") reduces the possibility of returning to the original, habitual form of system stability and thus provides a transition to a new level of functioning of the individual with a new attractor (found meaning). It will provide a more promising attraction of the system to stabilization. Therefore, existential-system analysis opens up opportunities to transform states, to reveal not only the nature of relationships between objects that make up a complex system, but also to prove and understand the role and importance of multiple combinations of interacting factors. They are elements of the system, the predominant states and the connections that make up the system. It also makes it possible to determine the causal relationships between objects from the standpoint of time. It provides a transition from fixing the phenomena that occur to understanding the structural relationships that generate certain sequences (patterns) of phenomena.

The general psychological transformation of activities and needs reveals the internal mechanism of creation (finding) of meanings, which is carried out according to the scheme of sequential action of a meaning formation, namely: indefinite, відчувається безпредметна тривога) $\rightarrow$ перетворення потреби і діяльності (безпредметна тривога опредмечується парафернальною здібністю репрезентувати внутрішній конфлікт, створюється "симптом-знак-текст) $\rightarrow$ задіяння методів семантичного аналізу порушень смислоутворення (відкриття парадоксальних смислів).

Таким чином, фокусом та механізмом реорганізації екзистенціально-системного концепту $\epsilon$ знаходження парадоксальних смислів та парадоксальна конфронтація із самим собою, зі своєю власною ідентичністю і тим світом, який клієнт створив для себе. Екзистенціально-системний ракурс впливу на життєвий стиль забезпечує дію механізму “збирання себе" і зміну зв'язків і відношень між елементами системи через розширення життєвого світу, через налаштування взаємодії з оточуючим середовищем через повторювальні патерни “співвіднесення зі світом" та самовіднесення і складання нової конфігурації смислового поля особистості.

Висновки. Психічна реальність, психічний образ, суб'єктивний образ - це конструкти, які континуально-дискретно характеризують індивідуальну систему створення людиною моделей реального світу і власну суб'єктивну психічну реальність як цілісну систему в її динаміці. Суб'єктивна модель реальності в якості просторово-часової структури змістовно складається зі смислів, що є проекцією та міні-моделлю дійсності. Означені міні-моделі генерують індивідуальну “картину світу" особистості, вибудовують унікальну її комбінацію та споруджують психічну конструкцію свідомості. Створена архітектоніка свідомості, в свою чергу, зумовлює процес подальшого відбиття з унікальними для людини зафіксованими головними координатними осями і пріоритетними крапками, масштабом, топографією та типовою емоційною забарвленістю “картини світу” й її окремих елементів.

Екзистенціально-системний концепт в силу транстеоретичних засад та завдання інтегрувати минулий досвід 3 безмежною власною інтенціальністю, в силу інтрапсихічного фокусу трансформаційної роботи, може розглядатися як ефективна площина зміни “кристалізованих" патернів, відкриття нових векторів власної екзистенції, самоорганізації 
Conceptualization of the existential-system model of reorganization of the "worldview" of the personality: the introduction of ontological dominants

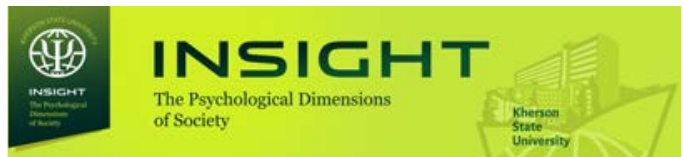

pointless state of a need (unconscious conflict between unaccepted, displaced personal meaning and need state) $\rightarrow$ the choice of a specific motive-object of a need (the state of need is not realized, there is a pointless anxiety) $\rightarrow$ transformation of a need and activity (pointless anxiety is objectified by paraphernal ability to represent internal conflict, it creates a symptom-signtext) $\rightarrow$ the use of methods of semantic analysis of meaning-making disorders (discovery of paradoxical meanings).

Thus, the focus and mechanism of reorganization of the existential-systemic concept is the finding of paradoxical meanings and paradoxical confrontation with oneself, with self identity and the world that the client has created for himself. The existential-system perspective of influencing the lifestyle ensures the action of the mechanism of "self-assembly" and change of connections and relations between the elements of the system. It happens due to the expansion of the living world, through the adjustment of interaction with the environment, through the repetitive patterns of "correlation with the world" and self-attribution, compiling a new configuration of the semantic field of personality.

\section{Conclusions}

Mental reality, mental image, subjective image are constructs that continuously and discretely characterize the individual system of a creation of real world's models and own subjective mental reality as a holistic system in its dynamics. The subjective model of reality as a space-time structure consists of meanings, which are a projection and a mini-model of reality. These mini-models generate an individual "worldview" of a personality, build its unique combination and create a mental structure of consciousness. The created architectonics of consciousness determines the process of further reflection with unique for a person fixed main coordinate axes and priority points, scale, topography and typical emotional color of the "worldview" and its individual elements.

The existential-system concept is based on transtheoretical principles and the task of integrating experience with infinite own intentionality, it has an intrapsychic focus of transformational work. Due to this, it can be considered as an effective plane of change of "crystallized" patterns, the discovery of new vectors of their own exist- та еволюціонування особистості. Таким чином, екзистенціально-системний концепт - це транстеоретична психологічна система забезпечення процесу смислової динаміки свідомості особистості 3 метою максимального проживання та "виконання" нею свого життя з автентичними установками, свободою і відповідальністю щодо власної екзистенції та світу. Концептуалізація екзистенціально-системного підходу визначила п'ять проекцій дослідження екзистенціальної дійсності людини, а саме: визначення шляхів усвідомлення власної екзистенції у світі; означення рушійних сил особистісних змін (виклики різноманітності, невизначеності, вибору, резиґнації та складності); понятійна операціоналізація онтологічних домінант концепту (з боку дій фахівця) і побудова змістової моделі взаємозв'язку понять концепту(з боку репрезентації екзистенції клієнта); обгрунтування взаємодоповнення діагностичних підходів (екзистенціального, системного моделювання та психодрами, проективного, психосемантичного, бодинамічного і трансперсонального); фундація єдності діагностики та реорганізації смислової архітектоніки свідомості особистості.

Подальший дослідницький інтерес полягає у висвітлені процесуальної логіки й гіпотетичного механізму трансформаційної дії екзистенціально-системного підходу, в побудові універсального алгоритму практичної дії психолога-консультанта, який окреслюється на багатовекторній координатній площині концепту та складається з: мети; рівня змін об’єкту; процесу змін - одиниць аналізу, елементів контакту, операційних технік, базових навиків, факторів впливу; стадій змін.

\section{Список використаних джерел}

Агафонов А. Ю. Основы смысловой теории сознания. Санкт-Петербург: Речь, 2003. 296 с.

Братусь Б.С. \& Лишин О.В. Закономерности развития деятельности и проблемы психологопедагогического воздействия на личность. Вестник МГУ. Серия 14. Психология, 1982. № 1. C. 12-21.

Гроф С. Путешествие в поисках себя. Москва: АСТ, 2008. 352 c.

Дружинин В.Н. Варианты жизни. Очерки экзистенциальной психологии. СанктПетербург: Иматон-М, 2010. 160 с.

Каліщук С.М. Методика Фреда Е. Фідлера 
ence, self-organization and evolution of personality. Thus, the existential-system concept is a transtheoretical psychological system of ensuring the process of semantic dynamics of the individual's consciousness in order to live and "fulfill" a life with authentic attitudes, freedom and responsibility for existence and the world. The conceptualization of the existential-system approach has identified five projections of the study of human existential reality. They are: an identifying ways of realizing a self existence in the world; identification of the driving forces of personal change (challenges of diversity, uncertainty, choice, resignation and complexity); conceptual operationalization of ontological dominants of the concept (from the actions of the specialist) and construction of the semantic model of interrelation of concepts (based on the representation of the client's existence); substantiation of complementarity of diagnostic approaches (existential, system modeling and psychodrama, projective, psychosemantic, body-dynamic and transpersonal); a foundation of the unity of diagnostics and reorganization of the semantic architectonics of personality consciousness.

Further research interest lies in the coverage of procedural logic and hypothetical mechanism of transformational action of the existential-system approach, as well as in the construction of a universal algorithm of psychologist-consultant's practical action. It is outlined on the multi-vector coordinate plane of the concept and consists of: purpose; level of change - the object; process of change - units of analysis, elements of contact, operational techniques, basic skills, factors of influence; stages of change.

\section{References}

Adler, A. (1932). What life should mean to you. London: George Allen \& Unwin Ltd.

Agafonov, A.Yu. (2003). Fundamentals of the semantic theory of consciousness. St. Petersburg, Spb.: Speech.

Almaas, A.H. (1996). Essence - the diamond approach to inner realization. York Beach: Samuel Weiser.

Bratus, B.S., \& Lishin, O.V. (1982). Patterns of development of activity and problems of psychological and pedagogical influence on a personality. Bulletin of Moscow State University, 1, 12-21.

Druzhinin, V.N. (2010). Variants of life. Essays on existential psychology. St. Petersburg: Imaton-M.

Grof, S. (2008). Traveling in search of yourself. Moscow: AST. та вірогідність зміни установки особистості щодо інших. Вісник Харківського національного педагогічного університету імені Г. С. Сковороди. Психологія. 2014. Вип. 48. С. 112-122. Режим доступу: http://nbuv.gov.ua/ UJRN/VKhnpu_psykhol_2014_48_15

Каліщук С.M. Системне моделювання як інтегративний метод особистісних змін й усвідомлення багато-варіативності життєвої реальності. Актуальні проблеми психології: Збірник наукових праць Інституту психології імені Г. С. Костюка: Психологія навчання. Генетична психологія. Медична психологія. Київ, 2018. Том Х. Вип. 31. С. 55-64. Режим доступу: http://www.appsychology.org.ua/data/ jrn/v10/i31/8.pdf

Kalishchuk S.N. Subjective Model of Reality: Origin of Construction.Problems of Modern Psychology : Collection of research papers of Kamianets-Podilskyi National Ivan Ohiienko University, G.S. Kostiuk Institute of Psychology of the National Academy of Educational Sciences of Ukraine Issue 47. Kamianets-Podilskyi: Ruta, 2020a. P. 93-118.DOI: 10.32626/2227-6246.2020-47.93-117.

Kalishchuk S.N. Notional Architectonics of Consciousness and Transformation of the Existential and Systemic Concept "Model of the World" of Future Psychologists who Have Their Professional Activity in the Sphere of Psychological Counseling. Problems of Modern Psychology: Collection of research papers of Kamianets-Podilskyi National Ivan Ohiienko University, G.S. Kostiuk Institute of Psychology of the National Academy of Educational Sciences of Ukraine Issue 47. Kamianets-Podilskyi: Ruta, 2020 б. P.154-174DOI: 10.32626/22276246.2020-48.154-174.

Кибед М., Шпаррер И. Совсемнаоборот. Москва: Институт консультирования и системных решений, 2014.256 с.

Ковалев С.В. Психотерапия личной истории и психокоррекция Самостоятельных Единиц Сознания. Москва: Московский психологосоциальный институт, 2001. 143 с.

Леонтьев Д.А. Синергетика и личность: к неравновесной персонологии. Методология и история психологии. 2018. Вып. 3. С. 96-104.DOI: 10.7868/S1819265318030068.

Максименко С.Д. Генезис существования личности. Киев: КММ, 2006. 240 с.

О’Коннор Дж., Макдермотт Дж. Искусство системного мышления: Необходимые знания о системах и творческом подходе к решению проблем. Москва: АльпинаБизнес Букс, 2006. $256 \mathrm{c}$.

Прохазка Дж., Норкросс Дж. Системы психотерапии. Для консультантов, психотерапевтов и психологов. Санкт-Петербург: Прайм- ЕВРОЗНАК, 2007. 383c. 
Conceptualization of the existential-system model of reorganization of the "worldview" of the personality: the introduction of ontological dominants

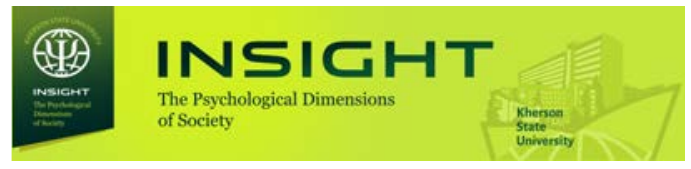

Kalishchuk, S.M. (2014). The method of Fred E. Fidler and the probability of changing the attitude of a personality in relation to others. Bulletin of G. S. Skovoroda Kharkiv National Pedagogical University, 48, 112-122. Access mode: http:// nbuv.gov.ua/UJRN/VKhnpu_psykhol_2014_48_15

Kalishchuk, S.M. (2018). System modeling as an integrative method of personal changes and awareness of the multi-variability of life reality. Actual Problems of Psychology. Collection of Scientific Papers of G. S. Kostiuk Institute of Psychology NAPS Ukraine", 10(31), 55-64. Access mode: http://www.appsychology.org.ua/data/jrn/v10/i31/8.pdf

Kalishchuk, S.N. (2020a). Subjective Model of Reality: Origin of Construction. Problems of Modern Psychology : Collection of research papers of Kamianets-Podilskyi National Ivan Ohiienko University, G.S. Kostiuk Institute of Psychology of the National Academy of Educational Sciences of Ukraine, 47, 93-118. DOI: $10.32626 / 2227-6246$

Kalishchuk, S.N. (2020b). Notional Architectonics of Consciousness and Transformation of the Existential and Systemic Concept "Model of the World" of Future Psychologists who Have Their Professional Activity in the Sphere of Psychological Counseling. Problems of Modern Psychology: Collection of research papers of Kamianets-Podilskyi National Ivan Ohiienko University, G.S. Kostiuk Institute of Psychology of the National Academy of Educational Sciences of Ukraine, 47, 154-174. DOI: 10.32626/2227-6246

Kibed, M., Shparrer, I. (2016). Quite the contrary. Moscow: Institute of Consulting and System Solutions.

Kovalev, S. V. (2001). Psychotherapy of a personal history and psychocorrection of independent units of consciousness. Moscow: Moscow Psychological and Social Institute.

Leontiev, D. A. (2018). Synergetics and personality: towards nonequilibrium personology. Methodology and the history of psychology, 3, 96-104. DOI: 10.7868 / S1819265318030068

Maksimenko, S. D. (2006). Genesis of the existence of personality. Kiev: KMM.

O'Connor, J., \& McDermott, J. (2006). The Art of Systems Thinking: Essential knowledge of systems and creative approach to solving problems. Moscow: Alpina Business Books.

Prochazka, J. \& Norcross, J. (2000). Psychotherapy Systems. For consultants, psychotherapists and psychologists. St. Petersburg: Prime EUROZNAK.

Psychotherapy - what is it? (2000). Modern ideas / Ed. Zeig, J., Munion, W. Moscow: Class.

Serkin, V.P. (2008). Methods of psychology of subjective semantics and psychosemantics. Moscow: Bee.

Tsapkin, V.N. (2004). The unity and diversity of therapeutic experience. Moscow: Moscow State Pedagogical University.

Varela, F. (1995). Resonant Cell Fssemblies. Biological Research.
Психотерапия - что это? Современные представления / Под ред. Дж. Зейга, В. Мьюниона. Москва: Класс, 2000. 432 с.

Серкин В.П. Методы психологии субъективной семантики и психосемантики. Москва: Пчела, 2008. 382 c.

Цапкин В.Н. Единство и многообразие терапевтического опыта. Москва: МГППУ, 2004. 199 с.

Adler A. What life should mean to you. London: George Allen \& Unwin Ltd., 1932. 300 p.

Almaas A.H. (1996) Essence - the diamond approach to inner realization. York Beach: Samuel Weiserю.1996.167p.

Varela F. Resonant Cell Fssemblies. Biological Research. 1995. P. 81-95. 